\title{
Inhibitory activity of Indian spice plant Cinnamomum zeylanicum extracts against Alternaria solani and Curvularia lunata, the pathogenic dematiaceous moulds
}

\author{
Ajay K Mishra ${ }^{1}$, Amita Mishra ${ }^{1}$, HK Kehri ${ }^{2}$, Bechan Sharma ${ }^{1}$ and \\ Abhay K Pandey*1
}

Address: ${ }^{1}$ Department of Biochemistry, University of Allahabad, Allahabad, 211002, India and ${ }^{2}$ Department of Botany, University of Allahabad, Allahabad, 211002, India

Email: Ajay K Mishra - ajaybiochem@gmail.com; Amita Mishra - amitamishra18@rediffmail.com; HK Kehri - kehrihk@rediffmail.com; Bechan Sharma - sharmabi@yahoo.com; Abhay K Pandey* - akpandey23@rediffmail.com

* Corresponding author

Published: 7 March 2009

Annals of Clinical Microbiology and Antimicrobials 2009, 8:9 doi:10.1 186/1476-07I I-8-9

This article is available from: http://www.ann-clinmicrob.com/content/8/l/9

(C) 2009 Mishra et al; licensee BioMed Central Ltd.

This is an Open Access article distributed under the terms of the Creative Commons Attribution License (http://creativecommons.org/licenses/by/2.0), which permits unrestricted use, distribution, and reproduction in any medium, provided the original work is properly cited.
Received: 22 December 2008

Accepted: 7 March 2009

\begin{abstract}
Background: Dematiaceous moulds are pathogenic microorganisms and act as etiological agents of mycoses with different degrees of severity in humans and animals. These moulds also cause loss of food crops and storage food products. The information regarding antimicrobial efficacy of the plant preparations on these moulds is scanty. The present study reveals phytochemical characterization and the effect of bark and leaf extracts of Indian spice plant, Cinnamomum zeylanicum $(\mathrm{Cz})$, against the growth of two species of dematiaceous moulds, Alternaria solani and Curvularia lunata.
\end{abstract}

Methods: $\mathrm{Cz}$ bark and leaf samples were sequentially extracted in different solvents using Soxhlet apparatus. Phytochemical analyses of extracts were done as per standard protocols. The antifungal bioassay of extracts was done by hanging drop technique. The inhibition of fungal spore germination was monitored under influence of three different concentrations of extracts.

Results: The lowest test concentration $(50 \mu \mathrm{g} / \mathrm{ml})$ of extracts of $\mathrm{Cz}$ bark prepared into acetone and that of $\mathrm{Cz}$ leaf into petroleum ether and ethanol exhibited complete inhibition (100\%) of spore germination in both the moulds. At $100 \mu \mathrm{g} / \mathrm{ml}$ concentration all the extracts showed about 50 to $100 \%$ inhibition. However, the treatment of the spores of the two fungal species with highest concentration $(500 \mu \mathrm{g} / \mathrm{ml})$ of bark and leaf extracts in all the solvents showed $100 \%$ fungicidal activity as it completely arrested the germination of spores. Relatively lower activity of aqueous extracts at 50 and $100 \mu \mathrm{g} / \mathrm{ml}$ concentrations suggests that the antifungal ingredients present in $\mathrm{Cz}$ bark and leaf are more soluble in organic solvents than water.

Conclusion: The results demonstrated that the $\mathrm{Cz}$ bark and leaves contain certain fungicidal constituents exhibiting potential antimould activity against $A$. solani and $C$. lunata. 


\section{Background}

The dematiaceous moulds are characterized by presenting melaninogenic pigmentation in their cell walls. It is the main characteristic of the dark moulds group. Some authors have reported dematiaceous moulds as opportunistic pathogens generally with low pathogenicity which could get into the human or animal body by repeated traumatic inoculation $[1,2]$. The two dematiaceous moulds such as Alternaria spp. and Curvularia spp. are known potential etiological agents of various mycoses with clinical forms ranging from localized superficial infections of the stratum corneum (Tinea nigra) to subcutaneous cysts (phaeomycotic cyst) to invasion of the brain [3]. The anti-dematiaceous moulds therapy has been carried out by the use of some antibiotics such as amphotericin B, 5-fluorocitosin and itraconazole [4,5]. Curvularia has been reported to cause infections in both humans and animals [6-9].

Dematiaceous moulds are also plant pathogens and cause diseases of cultivated crops posing serious threat to increased agricultural production. The protection of plants from pathogens has always been of prime concern in order to get better yield. Alternaria solani causes a destructive foliar disease in potato and tomato plants (family solanaceae) known as early blight. The early symptoms are in the form of small, yellowish brown spots on the leaves, which enlarge in size and become round to form black concentric rings, often killing most of the plant in the long run. Seeds infected with this pathogen may even damp off during germination. Another damatiaceous mould is Curvularia. Most species of this fungus are facultative pathogens of plants and cereals in tropical or subtropical areas, while the remaining is found in temperate zones. In addition to many other crops, Curvularia grows on paddy [10] causing leaf spots, blights, grain deformation, grain discolouration and even root rot.

The phytochemicals acting as antimicrobials represent a vast untapped source for medicines and hence have enormous therapeutic potential. They are effective in the treatment of infections while mitigating many of the side effects associated with synthetic antimicrobial and antibacterial agents $[11,12]$. The pharmacologically active plants have supplied over $25 \%$ of prescription drugs used in human medicine. In addition, as there is always a need to develop new biofungicides from natural plant sources; some plant products have been shown to act as natural pesticides [13].

There are some reports on antimicrobial activity of Cinnamomum zeylanicum $(\mathrm{Cz})$ against Gram positive and Gram negative bacteria, viruses, moulds and yeasts. The results have ranged according to the microorganism and assayed product (essential oil, extracts, decoct, plant pow- der). Phytochemicals are small organic biomolecules generally hydrophobic and designated as naturally occurring antibiotics [14-16]. Antifungal property of phytochemicals could involve cytosolic hyperacidity, breakage of electrons transport chain, $\mathrm{H}^{+}$-ATPase inhibition, channels inhibition, intracellular and extracellular enzymes synthesis inhibition [17].

Though the antimicrobial activity of certain plant products such as extracts, essential oils and phytochemicals has been reported [18-20], the review of literature indicates that no systematic study has been conducted regarding application of phytochemicals extracted from Indian spice plant, $\mathrm{Cz}$, as antifungal agents. In the present communication, an endeavour has been made to determine phytochemical profiles of $\mathrm{Cz}$ bark as well as leaf extracts and to evaluate the antimould activity of these extracts against the germination of spores of two dematiaceous moulds such as Alternaria solani and Curvularia lunata.

\section{Methods}

Plant Material

The bark and leaves of $\mathrm{Cz}$ were collected from Forest Research Institute, Dehradun in October/November 2006. Freshly collected plant parts were shade-dried at room temperature for 10-15 days. Dried bark and leaf samples were separately crushed and ground into fine powder with mortar and pestle.

\section{Preparation of extracts}

Powdered plant materials were sequentially extracted with different solvents in a Soxhlet apparatus for $8 \mathrm{~h}$ according to the method described elsewhere [21]. The solvents used for extraction included petroleum ether (PE), benzene (BZ), chloroform (CH), ethyl acetate (EA), acetone (AC), ethanol (ET) and water (AQ). The respective extracts were filtered and dried under reduced pressure using rotary evaporator to yield solid/semisolid residues. The residues were lyophilized to get dry solid mass.

\section{Phytochemical analysis}

Qualitative phytochemical analysis of $\mathrm{Cz}$ bark and leaf extracts was done as follows:

\section{Tannins}

$20 \mathrm{mg}$ extract was dissolved in $2 \mathrm{ml}$ distilled water and filtered. $2 \mathrm{ml} \mathrm{FeCl}_{3}$ was added to the filtrate, blue-black precipitate indicated the presence of tannins [22].

\section{Alkaloids}

$20 \mathrm{mg}$ extract was dissolved in $2 \mathrm{ml}$ distilled water and filtered. To the filtrate, $2-4$ drops of $1 \% \mathrm{HCl}$ was added and steam was passed through it. To the $1 \mathrm{ml}$ of this solution 6 drops of Wagner's reagent was added. Brownish-red precipitate indicated the presence of alkaloids [22]. 


\section{Saponins}

To $0.5 \mathrm{ml}$ of the filtrate obtained in alkaloids test $5 \mathrm{ml}$ distilled water was added. Frothing persistence indicated the presence of saponins [22].

\section{Flavonoids}

$20 \mathrm{mg}$ extract was dissolved in $10 \mathrm{ml}$ ethanol and filtered. $0.5 \mathrm{ml}$ conc. $\mathrm{HCl}$ and magnesium ribbon were added to 2 $\mathrm{ml}$ filtrate. Development of pink-tomato red color indicated the presence of flavonoids [22].

\section{Terpenoids}

Salkovski test was performed using a small amount of extract solution. To this solution 5 drops of conc. $\mathrm{H}_{2} \mathrm{SO}_{4}$ and $1 \mathrm{ml}$ Chloroform were added. Change of yellow colour into red indicated the presence of terpenoids [23].

\section{Phenols/polyphenols}

A small amount of material was extracted in ethanol and evaporated to dryness. Residue was dissolved in distilled water and $0.5 \mathrm{ml}$ Folin-ciocalteau reagent was added followed by $2 \mathrm{ml} \mathrm{20 \%} \mathrm{Na}_{2} \mathrm{CO}_{3}$ solution. Development of bluish colour indicated the presence of phenols [24].

\section{Test moulds}

A. solani and C. lunata were isolated from soil on potato dextrose agar (PDA) plates. These dematiaceous moulds were grown and maintained on PDA slants at $28 \pm 1^{\circ} \mathrm{C}$. Following incubation for five days, the cultures were either utilized for test or stored at $4 \pm 1^{\circ} \mathrm{C}$ for further use. The organisms were subcultured once in every fifteen days and the purity of the cultures was checked regularly under microscope.

\section{Bioactivity testing}

For the study of antimould activity, several concentrations of extracts $(50,100$ and $500 \mu \mathrm{g} / \mathrm{ml})$ were prepared in $5 \%$ DMSO. Bioactivity of the extracts was determined by counting spore (conidia) germination at various concentrations of extracts after $5 \mathrm{~h}$ of incubation through hanging drop technique [25]. Briefly, the spores were isolated from PDA slants and transferred in $1 \mathrm{ml}$ of each extract prepared in 5\% DMSO. $50 \mu \mathrm{l}$ extract containing spores was transferred at the centre of glass coverslip and number of spores was counted with the help of microscope. The coverslips containing spore suspension were placed on different depression slides containing a drop of water. The slides along with hanging spore suspension were incubated for $5 \mathrm{~h}$ at $28 \pm 1^{\circ} \mathrm{C}$. The spores were further counted under microscope to evaluate the effect of extracts on germination. Blank test showed that $5 \%(\mathrm{v} / \mathrm{v})$ DMSO used in the preparations of the test solutions does not affect the spore germination of test organisms. All experiments were carried out in triplicate and data were expressed as mean \pm SEM. The bar diagrams were prepared using Graphpad Prism software.

\section{Results \\ Phytochemical Analysis}

Results of phytochemical analysis of $\mathrm{Cz}$ bark and leaf extracts are given in Table 1 and Table 2, respectively. Extracts were tested for the presence of phenols/polyphenols, flavonoids, terpenoids, tannins, alkaloids and saponins or the combinations thereof. Phenols and terpenoids were invariably present in all the bark extracts. However, only phenols were present in all the solvent fractions of leaf. The analysis of different bark and leaf extracts also showed presence of combinations of other phytochemical constituents.

Inhibition of spore germination by different plant extracts The inhibition of spore germination of two different species of moulds namely $A$. solani and C. lunata by extracts of $\mathrm{Cz}$ bark and leaves was examined at three different concentrations $(50,100$ and $500 \mu \mathrm{g} / \mathrm{ml})$. Both of the mould species were found sensitive to the treatment with these extracts. Results of antimould activity of bark and leaf extracts on A. solani are shown in Figures 1 and 2 while their effects on C. lunata are depicted in Figures 3 and 4.

\section{Effect of $C z$ bark extracts on the germination of spores from $A$. solani and $C$. Iunata}

The $\mathrm{Cz}$ bark extracts prepared in chloroform and acetone were found to be most active against germination of spores of $A$. solani as their lowest dose $(50 \mu \mathrm{g} / \mathrm{ml})$ was sufficient to prevent $100 \%$ germination (Fig. 1), while in case of $C$. lunata only acetone extract of bark could exert complete inhibitory effect (Fig. 3). The results demonstrated in Figure 1 reflected that at $50 \mu \mathrm{g} / \mathrm{ml}$ concentration, the extracts prepared into petroleum ether and ethanol exhibited about 90-95\% activity against spores' germination of

Table I: Phytochemial analysis C. zeylanicum bark extracts

\begin{tabular}{|c|c|c|c|c|c|c|c|}
\hline \multirow[b]{2}{*}{ Phytochemicals } & \multicolumn{7}{|c|}{ Extracts } \\
\hline & PE & $\mathrm{BZ}$ & $\mathrm{CH}$ & $\mathrm{EA}$ & $\mathrm{AC}$ & ET & $\mathrm{AQ}$ \\
\hline Phenol/polyphenols & + & + & + & $\mathrm{nt}$ & + & + & + \\
\hline Flavonoids & - & + & + & $\mathrm{nt}$ & + & + & - \\
\hline Terpenoids & + & + & + & $\mathrm{nt}$ & + & + & + \\
\hline Tannins & - & - & + & $\mathrm{nt}$ & + & + & + \\
\hline Alkaloids & + & - & - & nt & - & + & + \\
\hline Saponins & + & - & - & nt & - & + & nt \\
\hline
\end{tabular}

Phytochemical analysis of different extracts of $C$. zeylanicum bark was done as shown in Methods section. $\mathrm{PE}=$ petroleum ether; $\mathrm{BZ}=$ benzene; $\mathrm{CH}=$ chloroform; $\mathrm{EA}=$ ethyl acetate; $\mathrm{AC}=$ acetone; $\mathrm{ET}=$ ethanol; $\mathrm{AQ}=$ water; $\mathrm{nt}=$ not tested; $(+)$ present/detected; $(-)$ not detected. 
Table 2: Phytochemial analysis of $C$. zeylanicum leaf extracts

\begin{tabular}{|c|c|c|c|c|c|c|c|}
\hline \multirow[b]{2}{*}{ Phytochemicals } & \multicolumn{7}{|c|}{ Extracts } \\
\hline & PE & $B Z$ & $\mathrm{CH}$ & EA & $A C$ & ET & AQ \\
\hline Phenol/polyphenols & + & + & + & + & + & + & + \\
\hline Flavonoids & - & + & + & + & + & + & - \\
\hline Terpenoids & + & - & - & - & + & + & + \\
\hline Tannins & - & - & - & - & + & + & + \\
\hline Alkaloids & + & - & - & + & - & + & + \\
\hline Saponins & + & - & - & - & - & + & nt \\
\hline
\end{tabular}

Phytochemical analysis of different extracts of $C$. zeylanicum leaves was done as shown in Methods section. $\mathrm{PE}=$ petroleum ether; $\mathrm{BZ}=$ benzene; $\mathrm{CH}=$ chloroform; $\mathrm{EA}=$ ethyl acetate; $\mathrm{AC}=$ acetone; $\mathrm{ET}=$ ethanol; $\mathrm{AQ}=$ water; $\mathrm{nt}=$ not tested; $(+)$ present/detected; $(-)$ not detected

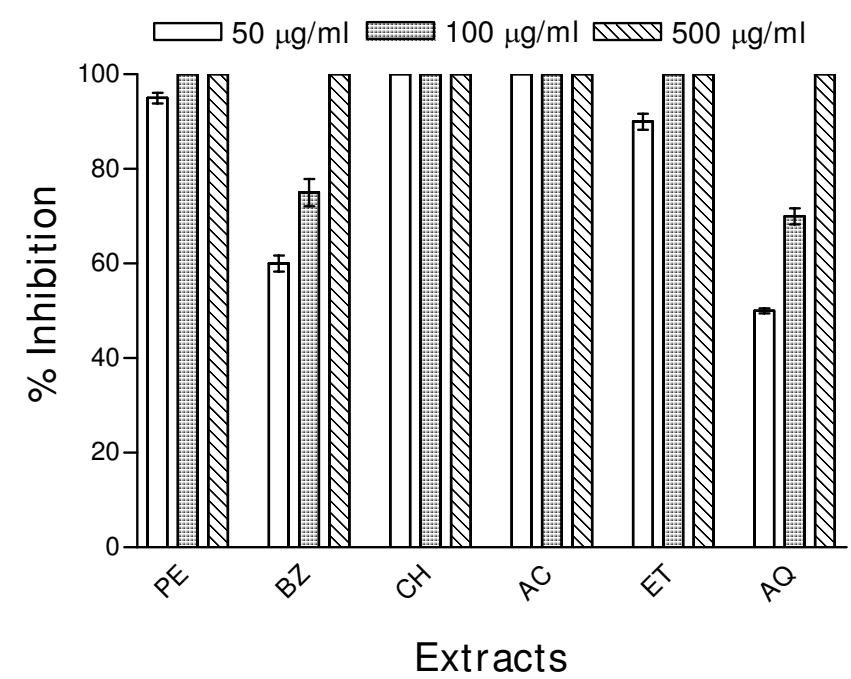

Figure I

Inhibition of germination of spores of $A$. solani by $C$. zeylanicum $(\mathbf{C z})$ bark extracts. The $\mathrm{Cz}$ bark extracts were prepared in (I) petroleum ether (PE), (2) benzene (BZ), (3) chloroform (CH), (4) acetone (AC), (5) ethanol (ET), and (6) water (AQ) as described in Methods section. Three concentrations $(50,100$ and $500 \mu \mathrm{g} / \mathrm{ml})$ have been used to evaluate the inhibitory activity of extracts against germination of spores of $A$. solani under experimental conditions as mentioned in experimental section.

A. solani, whereas those prepared in water and benzene could inhibit this activity by about 50 and 60\%, respectively. The inhibitory potential at all the three concentrations tested with extracts prepared into petroleum ether and chloroform were similar to those of ethanol and acetone, respectively. The bark extracts into petroleum ether,

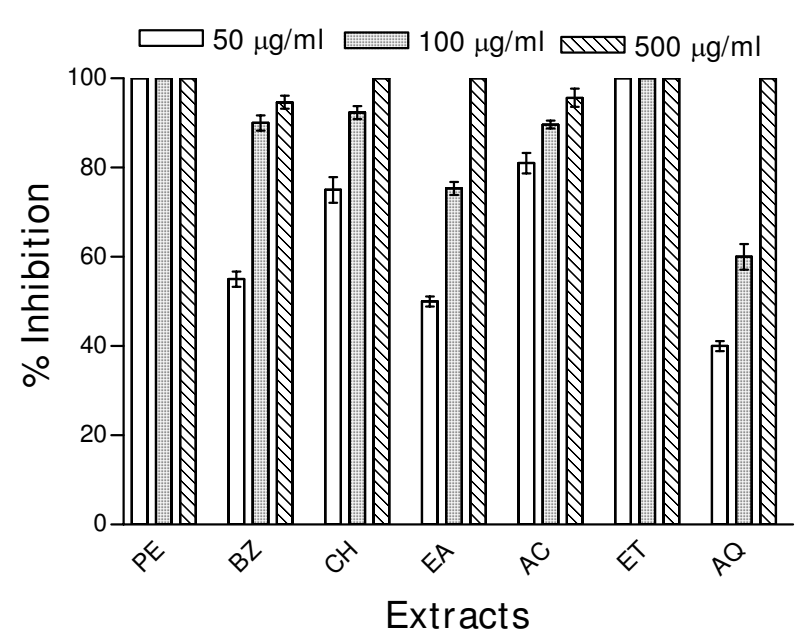

Figure 2

Inhibition of germination of spores of $A$. solani by $C$. zeylanicum $(\mathbf{C z})$ leaves extracts. The $\mathrm{Cz}$ leaves extracts were prepared in (I) PE, (2) BZ, (3) CH, (4) ethyl acetate (EA), (5) AC, (6) ET, and (7) AQ as described in Methods section. Other conditions were same as described in Fig. I.

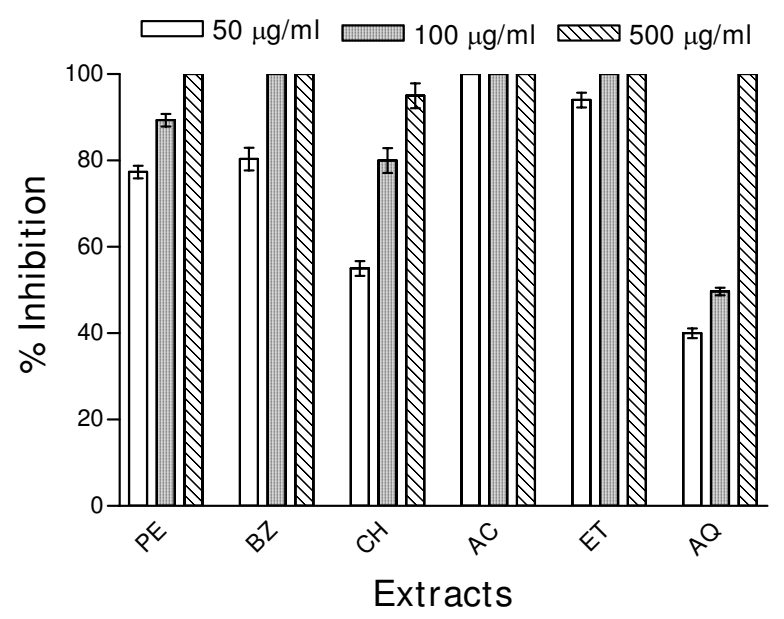

Figure 3

Inhibition of germination of spores of $C$. lunata by $C$. zeylanicum $(\mathbf{C z})$ bark extracts. The $\mathrm{Cz}$ bark extracts were prepared in (I) PE, (2) BZ, (3) CH, (4) AC, (5) ET, and (6) AQ as described in Methods section. Three concentrations $(50,100$ and $500 \mu \mathrm{g} / \mathrm{ml})$ have been used to evaluate the inhibitory activity of extracts against germination of spores of $C$. lunata under experimental conditions as mentioned in experimental section.

chloroform, acetone and ethanol completely arrested the spores germination of $A$. solani, whereas aqueous and benzene preparations could inhibit this activity by about 70 and $76 \%$, respectively, at $100 \mu \mathrm{g} / \mathrm{ml}$ concentration. The 


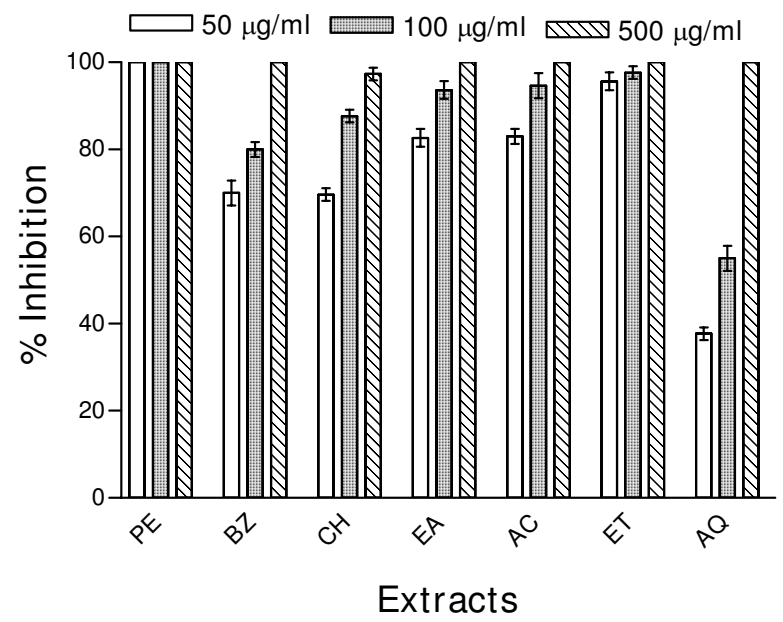

Figure 4

Inhibition of germination of spores of $C$. lunata by $C$. zeylanicum $(\mathbf{C z})$ leaves extracts. The $C z$ leaves extracts were prepared in (I) PE, (2) BZ, (3) $\mathrm{CH}$, (4) EA, (5) AC, (6) $E T$, and (7) AQ as described in Methods section. Other conditions were same as described in Fig. 3.

highest concentration $(500 \mu \mathrm{g} / \mathrm{ml})$ of all the extracts tested caused complete (100\%) inhibition of germination of $A$. solani spores. The inhibitory effect of these extracts from bark was found to be maximum with chloroform or acetone extract and minimum with aqueous preparation.

These extracts when tested against the germination of $C$. lunata spores displayed a different pattern (Fig. 3). The extract in acetone completely inhibited the germination of spores at minimum concentration tested $(50 \mu \mathrm{g} / \mathrm{ml})$. The ethanolic extract was almost equally active as it could show about 95\% inhibition at this concentration. However, other extracts at this concentration could display inhibitory effect up to $35-80 \%$ only. The bark extracts at higher concentration $(100 \mu \mathrm{g} / \mathrm{ml})$ could exhibit $100 \%$ inhibition in the spores' germination of $C$. lunata only when prepared in benzene, acetone and ethanol. The ethanol extract showed almost similar inhibitory pattern with that of acetone extract at all the three concentrations tested. The treatment of C. lunata spores with highest concentration $(500 \mu \mathrm{g} / \mathrm{ml})$ of all the test extracts resulted in almost complete inhibition of germination. The $\mathrm{Cz}$ extract in acetone was most active against $C$. lunata while the aqueous extract proved to be relatively least active (Fig. 3).

\section{Effect of $\mathrm{Cz}$ leaf extracts on the germination of spores from $A$. solani and $C$. lunata}

Since the data obtained from above experiments conducted with the extracts of bark demonstrated significant fungicidal potential, the attempts were made to evaluate the antifungal property of the extracts of leaves prepared in the aforesaid solvents. The results obtained after treat- ment of A. solani spores with the extracts of leaves showed a different trend in inhibitory activity. The data presented in Figure 2 indicated that the lowest concentration $(50 \mu \mathrm{g} /$ $\mathrm{ml}$ ) of leaves extracts prepared in ethanol and petroleum ether was most active and caused 100\% inhibition followed by the acetone, chloroform benzene and aqueous extracts. However, all other extracts of leaves were able to inhibit completely the spores' germination of $A$. solani only at the highest concentration $(500 \mu \mathrm{g} / \mathrm{ml})$. At lower concentrations (50 and $100 \mu \mathrm{g} / \mathrm{ml}$ ) all the extracts (excepting those prepared in petroleum ether and ethanol) registered only $40-80 \%$ and $60-95 \%$ inhibition, respectively. The aqueous extract from the leaves exhibited relatively lesser inhibitory activity at lower concentrations (Fig. 2). These extracts when tested against the germination of C. lunata spores, the lowest concentration of leaves extract prepared in petroleum ether could show complete $(100 \%)$ inhibition followed by the extracts prepared in other solvents (Fig. 4). The inhibitory activity pattern of the extracts prepared in benzene and ethyl acetate were similar to those of chloroform and acetone, respectively, at all the three concentrations tested. The ethanol extract exhibited close proximity in the inhibitory efficacy with that of petroleum ether extract at all the concentrations tested (Fig. 4).

The complete inhibition (100\%) of spore germination in both these moulds was observed with acetone extract of $\mathrm{Cz}$ bark (Figs. 1 and 3) as well as with petroleum ether and ethanol extracts of $\mathrm{Cz}$ leaf (Figs. 2 and 4 ) at the lowest concentration $(50 \mu \mathrm{g} / \mathrm{ml})$. At $100 \mu \mathrm{g} / \mathrm{ml}$ concentration all the extracts exhibited about $100 \%$ inhibition of spore germination of these two mould species. However, complete inhibition (100\%) of spore germination was observed at a concentration of $500 \mu \mathrm{g} / \mathrm{ml}$ for all extracts from both the bark and leaf. About 40-50\% reduction in spore germination was observed for these two moulds at the lowest test concentration $(50 \mu \mathrm{g} / \mathrm{ml})$ of aqueous extract.

\section{Discussion}

Antifungal susceptibility testing remains an area of intense interest. Susceptibility testing can be used for drug discovery and epidemiology. Number of reports is available showing efficacy of $\mathrm{Cz}$ essential oils as antimicrobial agents $[16,20]$. The oil extracted from Cz bark and leaves have been reported to possess fungicidal activity against fungi responsible for causing crown rot disease of banana. The major constituent possessing antifungal activity in $\mathrm{Cz}$ bark and leaf oils were found to be cinnamaldehyde and eugenol, respectively. In addition other compounds having fungicidal property have also been reported to be present in bark and leaves [26-28]. However, the data regarding use of $\mathrm{Cz}$ extracts as antifungal agents are scanty.

Despite serious environmental implications associated with the excessive use, chemical fungicides still remain the 
first line of defense against fungal pathogens. Moreover, these fungicides when ingested by human beings and animals through food and water cause various ailments in the body. Search of natural fungicidal principles from the plant sources would definitely be a better alternative to these hazardous chemicals. Our study has indicated the antimould potential of plant extracts, as the $\mathrm{Cz}$ bark and leaf extracts displayed complete inhibitory effect on spore germination of aforesaid two dematiaceous moulds.

The organic and aqueous extracts of $\mathrm{Cz}$ bark and leaves studied in the current work showed marked antimould activities against $A$. solani and C. lunata responsible for causing diseases in animals and plants as well as spoilage of stored food products. These organisms pose important public health and economic concerns for human society. However, the extracts differ significantly in their activity against the above moulds. The differences observed in the bioactivity assays suggest the susceptibility of these moulds to various secondary metabolites present in this endemic plant. The composition of these secondary metabolites in turn varies from species to species and also on climatic conditions and the physiological state of developments of the plants [29].

The relative antimould activity of $\mathrm{Cz}$ extracts may not be easily correlated with any individual component but with a mixture of compounds present in these extracts. There are reports showing that alkaloids and flavonoids are the responsible compounds for the antifungal activities in higher plants [30]. Moreover, secondary metabolites such as tannins and other compounds of phenolic nature are also classified as active antimicrobial compounds. Phenols, the aromatic compounds with hydroxyl groups are widespread in plant kingdom. They occur in all parts of plants. Phenols are said to offer resistance to diseases and pests in plants. Grains containing high amount of polyphenols are resistant to bird attack [24]. Interestingly, phytochemical screening of the current investigation has revealed that extracts from both the plant parts possess at least three to four of the following classes of secondary metabolites: phenols, flavonoids, terpenoids, tannins, alkaloids and saponins. Therefore, the presence of these phytochemicals could to some extent justify the observed antifungal activities in the current study. These results are in agreement with many studies realized on other plant species belonging to the euphorbiaceae [29] and asteraceae [31] attributing antimicrobial activities to the presence of secondary metabolites.

\section{Conclusion}

Our results have established the intense antimould potential of C. zeylanicum extracts against A. solani and C. lunata. It could be regarded as promising alternative antimicrobial preparation to be inserted in pharmaceutical formu- lations used to treat mycoses of different clinical severities and the plant diseases, particularly, those caused by dematiaceous moulds. The aforesaid Indian spice plant contains phytochemicals to be developed as prospective antifungal agents.

\section{Abbreviations}

Cz: Cinnamomum zeylanicum; A. solani: Alternaria solani; C. lunata: Curvularia lunata; PE: petroleum ether; BZ: benzene; $\mathrm{CH}$ : chloroform; EA: ethyl acetate; AC: acetone; ET: ethanol; AQ: water.

\section{Competing interests}

The authors declare that they have no competing interests.

\section{Authors' contributions}

AKP and BS participated in the research design, analysis of the data and drafting the manuscript. AKM and HKK carried out the antimicrobial activity tests. AKM and AM collected the materials for the extract preparation and conducted related experiments. All authors have read and approved the final manuscript.

\section{Acknowledgements}

AKM and AM acknowledge the financial support from University of Allahabad, Allahabad, India in the form of research fellowships.

\section{References}

I. Warnock DW, Johnson EM: Clinical manifestations and management of hyalohypomycosis, phaeohypomycosis and other uncommon forms of fungal infection in the compromised patient. In Fungal infection in the compromised patient Edited by: Warnock DW, Richardson MD. Chichester: John Willey \& Sons; 199|:756-789.

2. Wilhelmus KR: Climatology of dematiaceous fungal keratitis. Am J Ophthalmol 2005, I40: 1 156-I I 57.

3. Tamsikar J, Naidu J, Singh SM: Phaeohyphomycotic sebaceous cyst due to Cladosporium cladosporioides: case report and review of literature. J Med Mycol 2006, 16:55-57.

4. Minotto R, Bernardi CDV, Mallman LF, Edelweiss MIA, Scroferneker ML: Chromoblastomycosis: a review of 100 cases in the state of Rio Grande do Sul, Brazil. J Am Acad Dermatol 200I, 44:585-592.

5. Schwartz R: Superficial fungal infections. Lancet 2004, 364: $1173-1182$

6. Knudtson WU, Kirkbride CA: Fungi associated with bovine abortion in the northern plains states (USA). J Vet Diagn Invest 1992, 4(2): $181-185$.

7. Pitt JI, Hocking AD, Bhudhasamai K, Miscamble BF, Wheeler KA, Tanboon-Ek P: The normal mycoflora of commodities from Thailand. 2. Beans, rice, small grains and other commodities. Int J Food Microbiol 1994, 23:35-43.

8. Larone DH: Medically Important Fungi-A Guide to Identification 3rd edition. Washington DC: ASM Press; 1995.

9. St-Germain G, Summerbell R: Identifying Filamentous Fungi - A Clinical Laboratory Handbook Ist edition. Belmont, California: Star Publishing Company; 1996.

10. Benoit MA, Mathur SB: Identification of species of Curvularia on rice seed. Proc Int Seed Testing Assoc 1970, 35:99-119.

II. Mathews HB, Lucier WG, Fisher KD: Medicinal herbs in the United States: Research needs. Environ Health Perspec 1999, 107:773-778.

12. Bagghi AK: Alternative medicine - Old wine in a new bottle. J Indian Med Assoc 2000, 98(6):332-333. 
13. Sener B, Bingol F, Erdogan I, Bowers WS, Evans PH: Biological activity of some Turkish medicinal plants. Pure Appl Chem 1998, 70:403-406.

14. Delaquis PJ, Mazza G: Antimicrobial properties of isothiocyanate in food preservation. Food Technol 1995, 49:73-84.

15. Brul S, Coote P: Preservative agents in foods: mode of action and microbial resistance mechanisms. Int J Food Microbiol I999, 50:1-17.

16. Burt S: Essential oils: their antibacterial properties and potential applications in foods - a review. Int J Food Microbiol 2004, 94:223-253.

17. Lopez Diaz TML, González CJ, Moreno B, Otero A: Effect of temperature, water activity, $\mathrm{pH}$ and some antimicrobials on the growth of Penicillium oslonii isolated from the surface of Spanish fermented meat sausage. Food Microbiol 2002, 19: I-7.

18. Sahin F, Gulluce M, Daferera D, Sokmen A, Sokmen M, Polissiou M, Agar G, Ozer H: Biological activities of the essential oils and methanol extract of Origanum vulgare ssp vulgare in the Eastern Anatolia region of Turkey. Food Control 2004, 15:549-557.

19. Duarte MCT, Figueira GM, Sartoratto A, Rehder VLG, Delarmelina C: Anti-Candida activity of Brazilian medicinal plants. J Ethnopharm 2005, 97:305-3II.

20. Mishra AK, Mishra A, Bhargava A, Pandey AK: Antimicrobial activity of essential oils from the leaves of Cinnamomum spp. Natl Acad Sci Lett 2008, 3 I:341-345.

21. Pandey AK: Anti-staphylococcal activity of a pan-tropical aggressive and obnoxious weed Parthenium histerophorus: an in vitro study. Natl Acad Sci Lett 2007, 30:383-386.

22. Parekh J, Karathia N, Chanda S: Antibacterial activity of Bauhinia variegata. J Biomed Res 2006, 9:53-56.

23. Finar IL: Organic chemistry-vol 2: Stereochemistry and the chemistry of natural products. 5th edition. Delhi: Pearson Education (Singapore) India branch; 2003:769-7I.

24. Sadasivam S, Manickam A: Biochemical Methods 2nd edition. New Delhi: New Age International (P) Ltd; 1996:192-93.

25. Humphries J: Bacteriology. London: John Murray Albermack Street; 1974:452.

26. Ranasinghe L, Jayawardena B, Abeywickrama K: Fungicidal activity of essential oils of Cinnamomum zeylanicum (L) and Syzygium aromaticum (L) Merr et LM Perry against crown rot and anthracnose pathogens isolated from banana. Lett App Microbiol 2002, 35:208-II.

27. Montes BR, Carvajal M: Control of Aspergillus flavus in maize with plant essential oils and their components. J Food Prot 1998, 61:616-619.

28. Delespaul Q, Billerbeck VG, Roques CG, Michel G, Marquier-Vinuales C, Bessiere JM: The antifungal activity of essential oils as determined by different screening methods. J Essential Oil Res 2000, 1 2:256-266.

29. Mahomoodally MF, Gurib-Fakim A, Subratty AH: Antimicrobial activities and phytochemical profiles of endemic medicinal plants of Mauritius. Pharmaceutical Biol 2005, 43:237-242.

30. Cordell GA, Quinn-Beattie ML, Farnsworth NR: The potential of alkaloids in drug discovery. Phytother Res 200I, 15:183-205.

31. Boussaada O, Chriaa J, Nabli R, Ammar S, Saidana D, Mahjoub MA, Chraeif I, Helal AN, Mighri Z: Antimicrobial and antioxidant activities of methanol extracts of Evax pygmaea (Asteraceae) growing wild in Tunisia. World J Microbiol Biotechnol 2008, 24:1289-1296.

Publish with Biomed Central and every scientist can read your work free of charge

"BioMed Central will be the most significant development for disseminating the results of biomedical research in our lifetime. "

Sir Paul Nurse, Cancer Research UK

Your research papers will be:

- available free of charge to the entire biomedical community

- peer reviewed and published immediately upon acceptance

- cited in PubMed and archived on PubMed Central

- yours - you keep the copyright

Submit your manuscript here:

http://www.biomedcentral.com/info/publishing_adv.asp
BioMedcentral 